\title{
Efficacy of Electron Beam for Viral Inactivation
}

\section{Raymond W Nims ${ }^{1 *}$ and Mark Plavsic ${ }^{2}$}

${ }^{1} R M C$ Pharmaceutical Solutions, Inc., Longmont, CO, USA

${ }^{2}$ Corporate Product Biosafety, Genzyme, A Sanofi Company, Framingham, MA, USA

\begin{abstract}
The utility of electron beam as a physical approach for viral inactivation has been investigated to a limited extent, particularly for food safety and for applications for which other irradiation approaches such as gamma irradiation have produced unsatisfactory results or adverse impacts on the irradiated material. Viral inactivation by electron beam and gamma irradiation is mechanistically similar, though dose rate and penetrability into the irradiated material differ between the two approaches. In this paper, we have summarized the available data on the efficacy of electron beam for viral inactivation and the few studies that have directly compared the efficacy of electron beam and gamma irradiation for viral inactivation.
\end{abstract}

Keywords: Electron beam; Gamma irradiation; Enveloped viruses; Inactivation constant; Non-enveloped viruses

\section{Introduction}

The use of ionizing radiation for inactivation of viruses in foods and animal-derived materials used in the manufacture of bio therapeutics has certain advantages. Among these are the facts that the inactivant does not have to be cleared from the food or animal-derived material following the inactivation step and that irradiation is essentially a nonthermal process.

Ionizing radiation can constitute a number of forms. Most commonly employed for disinfection are gamma irradiation and electron beam. Gamma irradiation involves generation of gamma radiation, highly energetic photons of electromagnetic energy, typically from a ${ }^{60}$ cobalt source. Electron beam involves a highly charged stream of high-energy (typically 3-12 MeV) electrons generated through the acceleration and conversion of electricity. Unlike gamma irradiation, no radioactivity is associated with the generation of the electron beam.

Ionizing radiation inactivates viruses through direct and indirect pathways. The direct pathway is favored at low temperatures and in highly scavenging milieu (i.e., milieu containing proteins and other radiation-scavenging agents), and involves direct attack of radiation on cellular macromolecules (nucleotides, ribonucleotides, and to a lesser extent, proteins) as the predominant mode of action $[1,2]$. The indirect effect is favored at higher temperatures and in milieu that are relatively free of radiation-scavenging agents, and involves the generation of a substantial flux of free oxygen radicals (especially hydroxyl radical and hydrogen peroxide) following the radiolysis of water in addition to direct attack on the target macromolecules mentioned above.

While these inactivation mechanisms apply both to electron beam and gamma irradiation, there are some substantial differences in the characteristics of the two approaches. The primary differences relate to the penetrability of the radiation and the dose rate [3]. Gamma irradiation has much higher penetrability into materials than is the case for free electrons. The latter penetrate to a depth of $3-10 \mathrm{~cm}$, depending on the accelerator voltage and the density of the material being irradiated. To some extent, the lesser penetrability of the electron beam may be circumvented by irradiating a material simultaneously from two or more sides. On the other hand, the dose rate for electron beam is much higher than that for gamma irradiation, reducing the exposure (treatment) time required to attain a given fluency.

We previously have reviewed the gamma irradiation literature addressing the inactivation of potential viral and mycoplasma contaminants in frozen animal sera [4]. Electron beam has not typically been utilized for this purpose, primarily due to the penetrability constraints. On the other hand, electron beam has been evaluated for the disinfection of viral contaminants in foods (especially leafy vegetables, shellfish, and poultry), and in small volumes of liquids. We summarize these results in the present paper. There have been very few studies directly comparing the efficacy of gamma irradiation and electron beam irradiation for viral inactivation, and these have also been summarized herein.

\section{Methods}

Irradiation dose/viral inactivation response studies often display first-order kinetics with respect to administered fluency. This fact enables the results of such empirical studies to be expressed as an inactivation constant. In this paper, viral inactivation constants $(k)$ in units of $\log _{10}$ reduction in titer per kGy fluency have been chosen to represent the empirical results as opposed to the more commonly employed $D_{10}$ values $\left(D_{10}\right.$ = fluency required for a $1 \log _{10}$ reduction in viral titer). The former values can more easily be used to estimate inactivation efficacy for a virus for a given $\mathrm{kGy}$ fluency, as:

$\log _{10}$ reduction in titer $=k\left(\log _{10}\right.$ reduction in titer per kGy $) * k G y$ dose

And we find that this representation is more useful than the $D_{10}$ value. For instance, when the radiation dose in $k G y$ for a disinfection process is known from dosimetry, it becomes very straightforward and intuitive to estimate the $\log _{10}$ reduction of various viruses of concern by multiplying the fluency in kGy by the inactivation constants for those viruses. For those readers who are used to dealing with $D_{10}$ values, the latter may easily be obtained from the $k$ values presented herein, as:

$D_{10}=\frac{1}{k}$ (in units of $\mathrm{kGy} / 1 \log _{10}$ reduction in titer)

In the papers summarized herein, the viral inactivation constants

*Corresponding author: Raymond Nims, RMC Pharmaceutical Solutions, Inc. Longmont, CO USA, Tel: 301-639-9747; E-mail: rnims@rmcpharma.com

Received April 30, 2015; Accepted May 27, 2015; Published June 03, 2015

Citation: Nims RW, Plavsic M (2015) Efficacy of Electron Beam for Viral Inactivation J Microb Biochem Technol 7: 173-176. doi:10.4172/1948-5948.1000200

Copyright: $\odot 2015$ Nims RW, et al. This is an open-access article distributed under the terms of the Creative Commons Attribution License, which permits unrestricted use, distribution, and reproduction in any medium, provided the original author and source are credited. 
were either transformed directly from $D_{10}$ results provided, or were obtained as the slope of $\log _{10}$ inactivation vs. fluency $(k G y)$ plots generated from the reported results.

As the efficacy of irradiation approaches for viral inactivation has historically been shown to be matrix-dependent, the literature results summarized herein have been categorized separately for liquid matrices and food matrices.

\section{Efficacy of electron beam for virus inactivation in liquid matrices}

The literature addressing the efficacy of viral inactivation in liquid matrices by electron beam $[1,2,5-12]$ has been summarized in (Table 1). The liquid matrices have included a variety of aqueous tissue culture reagents, including culture media (Dulbecco's Modified Eagle Medium [DMEM], Minimal Essential Medium [Opti-MEM], RPMI 1640), buffered salt solutions (Hank's balanced salt solution [HBSS], phosphate buffered saline [PBS]), bovine serum, and bovine manure slurry ( $4.0 \%$ dry matter) and tap water. Irradiation temperatures used in these studies have included frozen $\left(-80^{\circ} \mathrm{C},-50^{\circ} \mathrm{C}\right.$ and unspecified frozen), refrigerated $\left(4^{\circ} \mathrm{C}\right)$ and ambient. The conditions have therefore included those favoring primarily the direct inactivation pathway (e.g., inactivation in bovine serum irradiated at $-50^{\circ} \mathrm{C}$, inactivation in media at $-78^{\circ} \mathrm{C}$ ), conditions favoring primarily the indirect pathway (e.g., inactivation in media, phosphate-buffered saline solution and tap water at ambient temperature), and conditions that might be expected to result in a mixture of the two pathways (e.g., inactivation in bovine serum at $4^{\circ} \mathrm{C}$, inactivation in bovine slurry at ambient temperature).

A total of 13 different mammalian/avian viruses representing eight families and three phages representing three families were examined in these studies. As shown in Tables 1 and 2, the viruses used to challenge the inactivation technology have included both enveloped and nonenveloped viruses, and viruses having differing genomic material (RNA vs. DNA) and strandedness.

It is evident from (Table 1) that under conditions favoring predominantly the indirect inactivation pathway (especially nonprotein containing matrices irradiated at ambient temperature), higher inactivation constants are obtained relative to conditions favoring the direct pathway (protein-containing solutions irradiated at lower temperatures). This is shown in particular by the data of Preuss et al. [5] for bovine serum irradiated at $-50^{\circ} \mathrm{C}$ vs. at $4^{\circ} \mathrm{C}$. The higher inactivation constants obtained at $4^{\circ} \mathrm{C}$ relative to those at $-50^{\circ} \mathrm{C}$ for porcine parvovirus, bovine viral diarrhea virus, and porcine enterovirus mean that a lower fluency is required to cause $4 \log _{10}$ inactivation of each virus at $4^{\circ} \mathrm{C}$ than is required at $-50^{\circ} \mathrm{C}$.

The data displayed in (Figure 1) further illustrate the matrixdependence of electron beam irradiation. A number of studies $[1,2,10,11]$ have examined the inactivation of the calicivirus murine norovirus-1 in phosphate-buffered saline or in DMEM. Relative to DMEM (which contains sugars, salts, amino acids, buffers, and $\mathrm{pH}$ indicators), phosphate-buffered saline represents a slightly less scavenging matrix. In each study comparing inactivation of the calicivirus in the two matrices [1,2,10], murine norovirus-1 was inactivated to a greater extent at a given fluency in phosphate-buffered saline than in DMEM. As shown in (Figure 1), the mean inactivation constants derived from the values in (Table 1) for irradiation of murine norovirus 1 in phosphate-buffered saline and DMEM are significantly different ( $p=0.01$ by ANOVA).

While there are insufficient data in (Table 1) to make valid conclusions on the relative susceptibilities of different virus families to electron beam irradiation, the lowest inactivation constants that have been reported are those for parvoviruses and retroviruses. This is in agreement with the relatively low efficacy observed in the case of gamma irradiation for inactivating parvoviruses and retroviruses, relative to other non-enveloped and enveloped virus families [4].

\section{Efficacy of electron beam for virus inactivation in food matrices}

Electron beam has recently been evaluated as a risk mitigation technology in the food industry [2, 9-11,13,14]. The model viruses that have been used to challenge the technology have therefore been those relevant to food safety. These have included seven different mammalian/avian viruses from five different families, modeling some agents of human health concern. As shown in Tables 2 and 3, the model viruses have included a variety of enteroviruses (various surrogates for the calicivirus human norovirus; the picornaviruses poliovirus and hepatitis $\mathrm{A}$, and the reovirus rotavirus) and influenza. Each are RNA viruses, and all but influenza are non-enveloped.

The matrices have included leafy vegetables (cabbage, lettuce,

\begin{tabular}{|c|c|c|c|c|}
\hline Matrix (temperature) & Virus & $\begin{array}{c}K \\
\left(\log _{10} /\right. \\
\mathrm{kGy})\end{array}$ & $\begin{array}{c}\text { kGy for } \\
4 \log _{10} \\
\text { inactivation }\end{array}$ & Ref. \\
\hline \multirow{3}{*}{ bovine serum $\left(-50^{\circ} \mathrm{C}\right)$} & porcine parvovirus & 0.085 & 47 & 5 \\
\hline & bovine viral diarrhea virus & 0.204 & 20 & 5 \\
\hline & porcine enterovirus & 0.156 & 26 & 5 \\
\hline \multirow{3}{*}{ DMEM $\left(-78^{\circ} \mathrm{C}\right)$} & pseudorabies virus & 0.179 & 22 & 6 \\
\hline & hepatitis A virus & 0.154 & 26 & 6 \\
\hline & porcine parvovirus & 0.116 & 34 & 6 \\
\hline RPMI $1640\left(-78^{\circ} \mathrm{C}\right)$ & $\begin{array}{l}\text { human immunodeficiency } \\
\text { virus-2 }\end{array}$ & 0.111 & 36 & 6 \\
\hline \multirow{3}{*}{$\begin{array}{l}\text { Hank's balanced salt } \\
\text { solution (frozen) }\end{array}$} & herpes simplex virus (Thea) & 0.141 & 28 & 7 \\
\hline & herpes simplex virus (Müller) & 0.141 & 28 & 7 \\
\hline & Rauscher leukemia virus & $\begin{array}{l}0.361 \\
0.117^{*}\end{array}$ & 34 & 7 \\
\hline \multirow{3}{*}{ bovine serum $\left(4^{\circ} \mathrm{C}\right)$} & porcine parvovirus & 0.130 & 31 & 5 \\
\hline & bovine viral diarrhea virus & 0.400 & 10 & 5 \\
\hline & porcine enterovirus & 0.227 & 18 & 5 \\
\hline $\begin{array}{l}\text { bovine slurry ( } 4 \% \text { dry } \\
\text { matter) (ambient) }\end{array}$ & bovine parvovirus & 0.284 & 14 & 8 \\
\hline $\begin{array}{l}\text { phosphate-buffered } \\
\text { saline }\left(4^{\circ} \mathrm{C}\right)\end{array}$ & avian influenza (H5N3) & 0.417 & 9.6 & 9 \\
\hline \multirow{6}{*}{$\begin{array}{l}\text { phosphate-buffered } \\
\text { saline (ambient) }\end{array}$} & murine norovirus-1 & 0.529 & 7.6 & 10 \\
\hline & murine norovirus-1 & 0.392 & 10 & 11 \\
\hline & murine norovirus-1 & 0.422 & 9.5 & 1 \\
\hline & murine norovirus-1 & 0.385 & 10 & 2 \\
\hline & Tulane virus & 0.543 & 7.4 & 2 \\
\hline & vesicular stomatitis virus & 0.773 & 5.2 & 1 \\
\hline Opti-MEM (ambient) & Tulane virus & 0.300 & 13 & 2 \\
\hline \multirow{4}{*}{ DMEM (ambient) } & murine norovirus-1 & 0.305 & 13 & 10 \\
\hline & murine norovirus-1 & 0.263 & 15 & 1 \\
\hline & murine norovirus- 1 & 0.275 & 15 & 2 \\
\hline & vesicular stomatitis virus & 0.616 & 6.5 & 1 \\
\hline \multirow{3}{*}{ tap water (ambient) } & bacteriophage $\mathrm{PHI}$ X 174 & 1.43 & 2.8 & 12 \\
\hline & bacteriophage MS2 & 10.0 & 0.4 & 12 \\
\hline & bacteriophage B40-8 & 50.0 & 0.1 & 12 \\
\hline
\end{tabular}

*Biphasic kinetics were attributed to two targets, Rauscher leukemia virus itself and a defective helper virus present in the virus stock (spleen focus forming virus) The kGy for $4 \log _{10}$ inactivation is based on the lowest $K$ value.

Table 1: Electron beam viral inactivation efficacy data: liquid matrices. 
Citation: Nims RW, Plavsic M (2015) Efficacy of Electron Beam for Viral Inactivation. J Microb Biochem Technol 7: 173-176. doi:10.4172/19485948.1000200

\begin{tabular}{|c|c|c|c|}
\hline Model Virus/Bacteriophage & Family & $\begin{array}{c}\text { Strandedness* } \\
\text { and Nucleic } \\
\text { acid }\end{array}$ & Lipid envelope \\
\hline porcine parvovirus & Parvoviridae & ssDNA & No \\
\hline bovine parvovirus & Parvoviridae & ssDNA & No \\
\hline porcine enterovirus & Picornaviridae & ssRNA & No \\
\hline hepatitis A virus & Picornaviridae & ssRNA & No \\
\hline poliovirus type 1 Chat & Picornaviridae & ssRNA & No \\
\hline murine norovirus-1 & Caliciviridae & ssRNA & No \\
\hline feline calicivirus & Caliciviridae & ssRNA & No \\
\hline Tulane virus & Caliciviridae & ssRNA & No \\
\hline rotavirus SA-11 & Reoviridae & dsRNA & No \\
\hline Rauscher leukemia virus & Retroviridae & dsRNA & Yes \\
\hline $\begin{array}{l}\text { human immunodeficiency } \\
\text { virus- } 2\end{array}$ & Retroviridae & dsRNA & Yes \\
\hline vesicular stomatitis virus & Rhabdoviridae & dsRNA & Yes \\
\hline bovine viral diarrhea virus & Flaviviridae & ssRNA & Yes \\
\hline avian influenza (H5N3) & Orthomyxoviridae & ssRNA & Yes \\
\hline pseudorabies virus & Herpesviridae & dsDNA & Yes \\
\hline herpes simplex virus (Thea) & Herpesviridae & dsDNA & Yes \\
\hline bacteriophage $\Phi \times 174$ & Microviridae & ssDNA & No \\
\hline bacteriophage MS2 & Leviviridae & ssRNA & No \\
\hline bacteriophage $\mathrm{B} 40-8$ & Siphoviridae & dsDNA & No \\
\hline
\end{tabular}

* Strandedness: ss, single-stranded; ds, double-stranded

Table 2: Characteristics of viruses used to challenge electron beam inactivation efficacy.

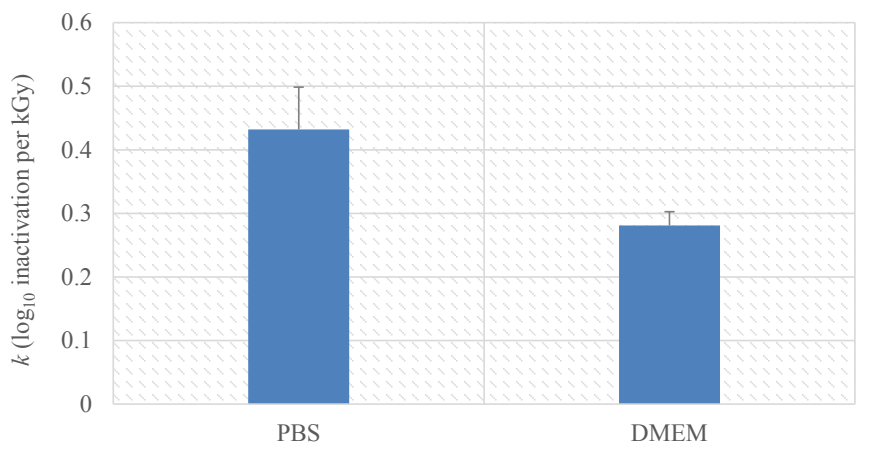

Figure 1: Efficacy for electron beam inactivation of the calicivirus murine norovirus 1 (MNV-1) at ambient temperature in phosphate-buffered saline $(n=4)$ vs. in DMEM $(n=3)$. Values are from Table 1 . The mean $k$ value for inactivation in phosphate-buffered saline is significantly different than that for inactivation in DMEM, $p=0.01$ (ANOVA)

and spinach), strawberries, oysters and poultry products. Irradiation for risk mitigation in the food industry is done primarily at ambient temperature, and this has been true of the various inactivation studies summarized in (Table 2). Under these conditions, both the direct and indirect inactivation pathways mentioned above would be expected to participate.

For each food category, the US FDA has established maximum irradiation fluencies which may be utilized for pathogen risk mitigation [15]. These maximum allowed fluency values may be used to estimate the extent of pathogen reduction ( $\log _{10}$ titer reduction) that might be achieved for the model viruses for which inactivation constants have been reported.

The results indicate that the efficacy of the allowed electron beam irradiation fluency for inactivation of viruses of concern (especially the caliciviruses and picornaviruses) is minimal and insufficient to warrant the use of this technology specifically for reduction of risk associated with these pathogenic viruses. On the other hand, electron beam has displayed moderate efficacy for inactivation of rotavirus on spinach or on iceberg lettuce (3.1 to $3.9 \log _{10}$ reduction in titer for the two food matrices, respectively [13] a closing parenthesis (Table 3).

\section{Direct comparisons of electron beam and gamma irradiation for virus inactivation}

Only two studies were found in which the efficacy of electron beam and gamma radiation for viral inactivation have been compared directly $[7,12]$. These studies are summarized below and in (Table 4).

Smolko and Lombardo (2005) evaluated the inactivation of two

\begin{tabular}{|c|c|c|c|c|c|}
\hline $\begin{array}{c}\text { Matrix } \\
\text { (temperature) }\end{array}$ & Virus & $\begin{array}{c}K\left(\log _{10} l\right. \\
\text { kGy })\end{array}$ & $\begin{array}{c}\text { FDA-allowed } \\
\text { irradiation } \\
\text { fluency* }^{*}\end{array}$ & $\begin{array}{l}\log _{10} \\
\text { inactivation } \\
\text { at allowed } \\
\text { fluency }\end{array}$ & Ref. \\
\hline $\begin{array}{l}\text { Cabbage } \\
\text { (ambient) }\end{array}$ & murine norovirus- 1 & 0.218 & $4.0 \mathrm{kGy}$ & $<1$ & 10 \\
\hline \multirow{2}{*}{$\begin{array}{l}\text { Strawberry } \\
\text { (ambient) }\end{array}$} & murine norovirus- 1 & 0.179 & \multirow{2}{*}{1.0 kGy } & $<1$ & 10 \\
\hline & Tulane virus & 0.322 & & $<1$ & 2 \\
\hline \multirow{4}{*}{$\begin{array}{l}\text { Lettuce } \\
\text { (ambient) }\end{array}$} & feline calicivirus & 0.339 & \multirow{4}{*}{$4.0 \mathrm{kGy}$} & 1.4 & 14 \\
\hline & Tulane virus & 0.333 & & 1.3 & 2 \\
\hline & rotavirus SA-11 & 0.971 & & 3.9 & 13 \\
\hline & $\begin{array}{c}\text { poliovirus type } 1 \\
\text { Chat }\end{array}$ & 0.431 & & 1.7 & 13 \\
\hline \multirow{2}{*}{$\begin{array}{l}\text { Spinach } \\
\text { (ambient) }\end{array}$} & rotavirus SA-11 & 0.775 & \multirow[b]{2}{*}{$4.0 \mathrm{kGy}$} & 3.1 & 13 \\
\hline & $\begin{array}{c}\text { poliovirus type } 1 \\
\text { Chat }\end{array}$ & 0.426 & & 1.7 & 13 \\
\hline \multirow{2}{*}{$\begin{array}{c}\text { Whole oysters } \\
\text { (ambient) }\end{array}$} & hepatitis A & 0.207 & \multirow{4}{*}{$5.5 \mathrm{kGy}$} & 1.1 & 11 \\
\hline & murine norovirus- 1 & 0.247 & & 1.4 & 11 \\
\hline \multirow{2}{*}{$\begin{array}{c}\text { Oyster } \\
\text { homogenate } \\
\text { (ambient) }\end{array}$} & hepatitis $A$ & 0.174 & & 1.0 & 11 \\
\hline & murine norovirus- 1 & 0.201 & & 1.1 & 11 \\
\hline $\begin{array}{l}\text { Egg white } \\
\text { (ambient) }\end{array}$ & $\begin{array}{l}\text { avian influenza } \\
\text { (H5N3) }\end{array}$ & 0.625 & 3.0 kGy & 1.9 & 9 \\
\hline $\begin{array}{l}\text { Ground } \\
\text { turkey meat } \\
\text { (ambient) }\end{array}$ & $\begin{array}{l}\text { avian influenza } \\
\text { (H5N3) }\end{array}$ & 0.385 & 3.0 kGy & 1.2 & 9 \\
\hline
\end{tabular}

*See reference 15

Table 3: Electron beam viral inactivation efficacy data: food matrices

\begin{tabular}{|c|c|c|c|c|c|c|}
\hline \multirow[b]{2}{*}{ Virus (strain) } & \multirow[b]{2}{*}{ Matrix (temperature) } & \multicolumn{2}{|c|}{ gamma irradiation } & \multicolumn{2}{|c|}{ electron beam } & \multirow[b]{2}{*}{ Ref } \\
\hline & & $\begin{array}{c}K\left(\log _{10} 1\right. \\
\text { kGy })\end{array}$ & $\begin{array}{c}\text { kGy for } \\
4 \log _{10}\end{array}$ & $\begin{array}{c}K\left(\log _{10} d\right. \\
k G y)\end{array}$ & $\begin{array}{c}\text { kGy for } \\
4 \log _{10}\end{array}$ & \\
\hline $\begin{array}{c}\text { herpes } \\
\text { simplex virus } \\
\text { (Thea) }\end{array}$ & $\begin{array}{c}\text { Hank's balanced salt } \\
\text { solution (frozen) }\end{array}$ & 0.368 & 11 & 0.141 & 28 & 7 \\
\hline $\begin{array}{c}\text { herpes } \\
\text { simplex virus } \\
\text { (Müller) }\end{array}$ & $\begin{array}{c}\text { Hank's balanced salt } \\
\text { solution (frozen) }\end{array}$ & 0.307 & 13 & 0.141 & 28 & 7 \\
\hline $\begin{array}{c}\text { Rauscher } \\
\text { leukemia virus }\end{array}$ & $\begin{array}{l}\text { Hank's solution } \\
\text { (frozen) }\end{array}$ & $\begin{array}{l}0.722 \\
0.198^{*}\end{array}$ & 20 & $\begin{array}{l}0.361 \\
0.117^{*}\end{array}$ & 34 & 7 \\
\hline $\begin{array}{l}\text { bacteriophage } \\
\Phi \times 174\end{array}$ & tap water (ambient) & 2.94 & 1.4 & 1.43 & 2.8 & 12 \\
\hline $\begin{array}{l}\text { bacteriophage } \\
\text { MS2 }\end{array}$ & tap water (ambient) & 10.0 & 0.4 & 10.0 & 0.4 & 12 \\
\hline $\begin{array}{c}\text { bacteriophage } \\
\text { B40-8 }\end{array}$ & tap water (ambient) & 22.2 & 0.2 & 50.0 & 0.1 & 12 \\
\hline
\end{tabular}

*Biphasic kinetics were attributed to two targets, Rauscher leukemia virus itself, and a defective helper virus present in the virus stock (spleen focus-forming virus). The kGy for $4 \log _{10}$ inactivation is based on the lowest $K$ value.

Table 4: Direct comparison of viral inactivation by gamma and electron beam irradiation. 
strains of herpes simplex virus and a retrovirus (Rauscher leukemia virus) by electron beam and gamma irradiation [7]. The inactivation matrix in each case was Hank's balanced salt solution irradiated at an unspecified temperature (referred to as "frozen" in the paper). The inactivation mechanism is expected therefore to have been mixed (i.e., involving both the direct and indirect pathways) for each irradiation modality. The results obtained for each virus indicated a higher inactivation constant for gamma irradiation than for electron beam irradiation. To achieve a $4 \log _{10}$ reduction of the herpes simplex viruses, the fluency required for electron beam ( $28 \mathrm{kGy})$ was estimated to be $>$ two times that required for gamma irradiation (11-12 kGy). To achieve a $4 \log _{10}$ reduction of the retrovirus, the fluency required for electron beam ( $34 \mathrm{kGy}$ ) was estimated to be $>1.7$ times that required for gamma irradiation $(20 \mathrm{kGy})$. In a study reported by Gehringer et al. (2003), the inactivation of three bacteriophages (viruses displaying infectivity for bacteria) by electron beam and gamma irradiation was directly compared [12]. The phage included MS2 (family Leviviridae), ФX174 (family Microviridae), and B40-8 (family Siphoviridae), and the inactivation matrix evaluated was tap water at ambient temperature. The latter conditions should have favored primarily the indirect inactivation pathway. No valid conclusions can be made from the data presented. It appears that MS2 was inactivated with similar kinetics by electron beam and gamma irradiation. Electron beam displayed greater efficacy than gamma irradiation for inactivating phage B40-8, while the opposite situation applied for phage $\Phi X 174$.

Additional comparative data for inactivation of viruses by these radiation modalities need to be generated prior to making much of any differences observed (Table 3). Theoretically, a given radiation fluency derived from electron beam should display inactivation efficacy similar to the same fluency derived from gamma irradiation, provided that factors determining penetrance of the radiation into the matrix do not influence the outcome.

\section{Conclusions}

A systematic review of the electron beam viral inactivation literature was performed to summarize the current status of the inactivation approach for viruses. Much of the empirical data reported thus far has been applicable to viruses of food safety concern. Food items for the most part are irradiated at ambient temperature, which might be expected to shift the balance toward the indirect inactivation pathway involving oxygen radicals derived from the radiolysis of water within the food. Although this might be expected to enhance the viral inactivation per $\mathrm{kGy}$, due to constraints that the FDA places on irradiation fluency permissible for food, the extent of viral inactivation actually achieved has, as a generality, been found insufficient for risk mitigation.

There is a potential for achieving viral inactivation of animalderived materials with electron beam at total exposure times much lower than required for gamma-irradiation. Certain porcine trypsin suppliers, for instance, utilize electron beam for viral risk mitigation rather than gamma-irradiation, in part to prevent adverse changes in the appearance of the material following irradiation. Whether or not the reduction in exposure time associated with electron beam necessarily will translate generally to a reduction in adverse radiation-induced impacts on the materials being irradiated still must be determined. This field requires much more basic research in the directions of viral inactivation and impact on irradiated materials.

\section{References}

1. Sanglay GC (2012) Inactivation and mechanism of electron beam irradiation and sodium hypochlorite sanitizers against a human norovirus surrogate. Dissertation, Ohio State University, Ohio.

2. Predmore A, Sanglay GC, DiCaprio E, Li J, Uribe RM,et al.(2015) Electron beam inactivation of Tulane virus on fresh produce, and mechanism of inactivation of human norovirus surrogates by electron beam irradiation. Int $J$ Food Microbiol 198: 28-36.

3. Silíndír M, Özer AY (2009) Sterilization methods and the comparison of e-beam sterilization with gamma radiation sterilization. FABAD J Pharm Sci 34: 43-53.

4. Nims RW, Gauvin G, Plavsic M (2011) Gamma irradiation of animal sera for inactivation of viruses and mollicutes - a review. Biologicals 39: 370-377.

5. Preuss T, Kamstrup S, Kyvsgaard NC, Nansen P, Miller A, et al.(1997) Comparison of two different methods for inactivation of viruses in serum. Clin Diagn Lab Immunol 4: 504-508.

6. Schmidt T, Hoburg AT, Gohs U, Schumann W, Sim-Brandenburg J-W, et al (2012) Inactivation effect of standard and fractionated electron beam irradiation on enveloped and non-enveloped viruses in a tendon transplant model Transfus Med Hemother 39: 29-35.

7. Smolko EE, Lombardo JH (2005) Virus inactivation studies using ion beams, electron and gamma irradiation. Nuclear Inst Meth Phys Res B 236: 249-253.

8. Skowron K, Paluszak Z, Olszewska H, Wieczorek M, Zimek Z, et al.(2014) Effectiveness of high energy electron beam against spore forming bacteria and viruses in slurry. Rad Phys Chem 101: 36-40.

9. Brahmakshatriya V, Lupiani B, Brinlee JL, Cepeda M, Pillai SD, et al.(2009) Preliminary study for evaluation of avian influenza virus inactivation in contaminated poultry products using electron beam irradiation. Avian Patho 38: $245-250$

10. Sanglay GC, Li J, Uribe RM, Lee K (2011) Electron-beam inactivation of norovirus surrogate in fresh produce and model systems. J Food Prot 74: 11551160.

11. Praveen C, Dancho BA, Kingsley DH, Calci KR, Meade GK, et al.(2013) Susceptibility of murine norovirus and hepatitis A virus to electron beam irradiation in oysters and quantifying the reduction in potential infection risks. Appl Environ Microbiol 79: 3796-2801.

12. Gehringer P, Eschweiler H, Leth H, Pribil W, Pfleger S, et al. (2003) Bacteriophages as viral indicators for radiation processing of water: A chemical approach. Appl Rad Isotop 58: 651-656.

13. Espinosa AC, Jesudhasan $P$, Arredondo R, Cepeda M, Mazari-Hiriart M, et al.(2012) Quantifying the reduction in potential health risks by determining the sensitivity of poliovirus type 1 Chat strain and rotavirus SA-11 to electron beam irradiation of iceberg lettuce and spinach. Appl Environ Microbiol 78: 988-993.

14. Zhou F, Harmon KM, Yoon K-J, Olson DG, Dickson JS (2011) Inactivation of feline calicivirus as a surrogate for norovirus on lettuce by electron beam irradiation. J Food Prot 74: 1500-1503.

15. US FDA 21CFR179.26 Irradiation in the production, processing and handling of food. 